\title{
An Analysis of Income Inequality and Education Inequality in Bahrain
}

\author{
Hisham H. Abdelbaki \\ Department of Economics, Mansoura University, Mansoura, Egypt \\ Email: habdelbaki@hotmail.com
}

Received July 5, 2012; revised August 1, 2012; accepted August 10, 2012

\begin{abstract}
This research investigates the income inequality and education inequality that still capture the interest of economists, socialists and politicians for its clear impact on all fields in the national economy. The main findings of the research are: first there is a positive association between the level of education of the head of the family and family income. Second, income inequality leads to education inequality between income-classes, which leads to widen the income gap between future generations. The third is inequality in education attainment in Bahrain had been declined during the period 1980-2006. Finally, the result stated that the main sources of education inequality in Bahrain are disparities in education costs, availability of private schools in different governorates, and in spending on education. The paper recommends that the policy-makers in Bahrain should pay more attention to distribution of private schools among governorates and education cost among these schools to improve the education inequality and income inequality situation in Bahrain.
\end{abstract}

Keywords: Income Inequality; Education; Education Inequality; Bahrain

\section{Introduction}

Education and education inequality are the most important factors affecting income inequality. Obtaining a better education-particularly in developing countries-means a higher level of income. At the same time, education expenses may well be beyond the reach of people with low income levels, thus poverty means obtaining less efficient education, or even not obtaining any education at all, which minimizes the chance of obtaining a job with adequate salary, and lead to a wider income gap between the rich and poor sectors of the community, therefore, education and income distribution are issues closely related to each other [1].

In the literature on human capital theory, Tanzi [2] stated that human capital is the most vital element, not only to push the wheels of growth and development, but also to boost the wheels of justice and equality in society. Thus, the human resource development holds great importance in terms that human is the goal, means and executer of the economic development process. Human resource development comes through increasing the skills and educational abilities, the level and quality of the available health and training services and this is referred to as "investment in human capital". In most countries, the level of education is one of the most important determinants of the wage level. Therefore, education is an important factor in determining the degree of equitable distribution of income in any society. For example, $50 \%$ of the income inequality in Brazil is interpreted through the disparity in educational level [3].

The interpretation of the human capital model was attributed to Adam Smith in his book (Wealth of Nations) in 1667 and recently to Schultz and Becker in his book "Human Capital" in 1964. The human capital model is the extension of the new-classic model determining wages and employment supply on the long run, and the idea revolves around the threshold product of the work factor. In this model, assuming that education and training will increase worker's productivity and hence wages, each individual takes a decision to determine the quantity and quality of education and training needed by him. There is no doubt that this decision is also beset by cost like direct cost through spending on education and training, as well as the indirect cost in the form income lost during time of training and education of labor. Then individuals choose to learn and train if the expected return after the process of education and training is higher or at least equal to the cost borne by the individual to choose alternative education and training.

Even with different analysis on the effect of education on the earned income, the relationship between education and income inequality is ambiguous. A number of studies have proved the existence of a positive relationship between education and training on the one hand ${ }^{1}$, and the abil-

\footnotetext{
${ }^{1}$ See the survey by Psacharopoulos and Wooddhall, 1985, pp. 264-270.
} 
ity to earn income on the other hand [4-9]. In contrast, many studies find that education and education inequality have no statistically significant effects on income inequality $[10,11]$. On the other side, some literature focused on the effects of types of education, private and public, on income inequality, for instance, Sylwester [12] argued whether or not education expenditure reduce income inequality. He used a cross-sectional data to measure the association between the change in income inequality level and public expenditure for education. His main finding is that devoting more resources to public education reduces income inequality. Glomn and Ravikumar [13] reported that income inequality declines under a private education system. However, it unambiguously decline under a public education system. The same results are stated by SaintPaul and Verdier [14], Eskstein and Zilcha [15] and Zhang [16] where public education can lower the level of income inequality over time. On contrast, Jimenez [17] stated that many public education expenditures do not benefit the poor at all, hence, have no positive effect on income inequality.

The main objectives of this study are to investigate income inequality and education inequality in Bahrain using household expenditure and income surveys and analyze the causality relationship between education inequality and income inequality over time.

The next section is devoted to analyze the sources of income distribution while section three discusses causality relationship between education inequality and income inequality. Education inequality and income inequality in Bahrain is analyzed in section four. Section five focuses on analysis of causes of education inequality in Bahrain. Finally, section six presents the concluding remarks.

\section{Sources of Income Inequality}

There are many causes for the income gap. The most important of these causes are education and training. As mentioned before, education is an important factor in determining the level of wage and thus contributes greatly to the distribution of initial income in society. Also, health and health care is an important determinant of the targeted and achieved degree of growth and development in a country. Economists confirm the existence of a close relationship between nutrition and the worker's ability to make the effort required of him, this relationship is called "the efficiency-wage function", it confirms that malnutrition leads to low productivity. In general we can say that in light of the targeted production technology, improving the level of health will lead to improved labor productivity according to the level of productivity/worker, and from here comes the impact of the health level on income distribution, where the rich and urban residents generally have access to better health care services than the poor and the countryside residents.
It is no secret that work is the primary source of income for the vast majority of individuals in all economies, and therefore employment and unemployment represent a significant cause of poor distribution of income. To analyze that, it is important to identify the working-age and labor force within the community, and the rate of participation in the labor force and unemployment types and rate.

Labor organizations play a clear role in reducing the income gap in the community through a package of benefits provided to workers, labor organizations are formed of workers working in one industry or group of industries, which means that there are different forms and levels of those organizations. The organizational form of labor regulations also differ according to the country, industry and possibly other factors. However, there are important units in those organizations which assume specific roles to defend the interests of workers, like the collective bargaining unit which takes the role of negotiating with employers to gain appropriate working conditions like wages, working hours and conditions of work and any other related issues. The world famous economist Alfred Marshall (8th edition, New York: Macmillan, 1920) studied the impact of labor organizations on the level of wages and employment of workers and concluded what is now known as the "Marshall rules", Marshall decides that the impact of labor organizations on the wages and employment of workers depends on the flexibility of demand for labor. The first rule decides that whenever the labor demand curve is inflexible, the role of labor organizations in the production process increases. The second rule indicates that whenever the demand curve on the produced item or service is inflexible, the demand curve for labor under the umbrella of labor organizations is inflexible. The third rule states that whenever the demand for workers under the umbrella of labor organizations is not flexible, the share of labor organizations from wages to the total production costs would decline. Finally the fourth rule states that whenever the demand curve for labor under the umbrella of labor organizations is flexible, the curve for supply of alternative factors of production is inflexible. Although labor organizations lead to an increased number of the unemployed, they contribute to reduce the pay gap between workers under the umbrella of these organizations-usually low-skilled labor-and workers who are not covered by the umbrella of these organizations - usually highly skilled workers [18-22]. In general, we can say that labor organizations contribute positively in reducing the income gap between the labor forces within the national economy. There is no doubt that the positive role of these different organizations depends on their effectiveness on one hand and the environment through which they operate like domestic legislation, type and structure of labor markets and the extent of participation of workers in unions and other organizations on the other hand. 
After years of work, saving represents an important factor in the stability of income level in the future. The model of life cycle that has been developed by Modigliani and Brumberg [23] indicates that families save to distribute consumption over the years of their lives. As the work period may extend up to the age of retirement, while perhaps the individual lives beyond that age, then they save on their working-age so as not to have to cut their spending after that age due to low income because of retirement. In the simplified image of the model, we assume that the level of income will be stable during the working-age, and with the assumption of a constant average savings also during those years without interest (zero interest rate), the net wealth generated will grow constantly and the wealth to age relationship curve takes the shape of an inverted "V". However, Ando and Modigliani [24] amended the assumption of zero interest, and assumed positive rate of interest that does not change with time, as a result the net wealth curve takes the shape of an inverted "U" [25].

Also another important factor affecting the degree of equitable distribution of income is the extent of racial discrimination in society between classes or categories, or perhaps certain sectors. Racial discrimination takes one of two forms: first, skills, competencies, expertise and capacity are all equal but discrimination is based on gender, for example, the discrimination between women and men merely because of sex difference. The second is discrimination in pay or benefits for employees in the same areas simply because they belong to different groups. In addition to the discrimination in wages and benefits, other forms of discrimination include: 1) Preference of employment to individuals belonging to certain groups, which spreads unemployment among other groups; 2) Difference in the rates of labor force participation among different groups; 3) Discrimination may also take the form of housing segregation, in the sense that individuals belonging to certain groups live in specific areas, and the best example of this type of racial discrimination is on the African Americans in the United States, where specific areas are allocated for them to stay. The question that comes to mind now is: What is the relationship of that with the justice of income distribution? Answer is that these areas lack the education and quality health care, hence affecting the skills, competencies and the ability of residents, and also affecting their ability to obtain a quality job, and finally, the income earned from that job $[26,27]$.

There are many theories trying to show the impact of racial discrimination on individuals and society, including the theory of the tendency for discrimination, statistical discrimination theory and the Marx theory of discrimination and the model of the discriminatory mark and finally the model of overcrowding. Becker [28] has provided the theory of the tendency for discrimination. It is based on the assumption that the employer tends to distinguish between workers. The theory of statistical discrimination was developed through contributions of Phelps [29], Arrow [30-32] and also Aigner and Cain [33]. The theory is based on two basic assumptions: 1) That the employer cannot determine the threshold productivity of the worker to be hired; and 2) That the employer has a vision or a general idea on the relative productivity of groups of workers, it is presumed that workers from a certain group have higher threshold productivity than workers belonging for another specific group. In contrast to the previous theory, the employer wants to maximize profits, as well as basing the analysis on internal objective. The third form of the Marxism theory is derived, where the hypothesis is based on the statute of Marx's view that there are two conflicting classes in capitalist society: employers and labors. And the division of GDP between these two classes leads to class struggle. This struggle takes its economic nature through strikes and collective bargaining, and its political nature through the formation of labor parties in many Western European countries and lobbies in the United States of America. The aim of the capitalist class is to constantly prevent the labor class from forming political parties or economic forces to defend them. One way to do that is the so-called Divide and Conquer Strategy, where the capitalists always try to create divisions among the labor class, but this strategy did not work and was not fruitful due to the increasing awareness of the labor class to their interests and increasing trade unions and labor political parties. Reich [34-38] explained that racial discrimination between these two classes has evolved to discrimination within the same class, Within the working class there became discrimination between women and men, as well as discrimination on the basis of race or descent, such as racial discrimination against black Americans according to their origin, and certain labor classes started to consider minorities as a threat to their jobs. Thus labor classes became divided among them, and consider each other as an enemy. Perhaps this model is more applicable to the current situation in the United States and explains the evolution of racial discrimination over time, from just discrimination between two different classes: businessmen and labors to racial discrimination within the working class itself. The fourth model for the interpretation of Racial Discrimination - the discriminatory mark - was introduced by Loury [39,40]. The theory decides that it is normal to distinguish individuals according to their physical appearance and attributes related to it, in order to deal with the social environment characterized by uncertainty. Based on that, discrimination is made between different classes within the same society and therefore treatment varies depending on the class. The fifth model explains racial discrimination according to sex. This model was presented for the first time by Bergmann [41] and newly developed by Stevenson [42], Blau \& Hendricks 
[43] and also Blau [44]. The model assumes the existence of separate jobs for women other than those for men, and since the business demand for women is less than the work force volume and the employment opportunities for men are much greater, the prevailing wages of women is lower compared to men. There is no doubt that racial discrimination in all its forms leads to many economic, social and political problems. The severity of these problems increases as racial discrimination increases, leading to increased class and racial hatred, poverty, slums and increased number of outlaws, and crimes of all kinds leading to several negative effects on national economy on the one hand and on the distribution of income on the other hand. The starting point for the analysis of discrimination is to measure discrimination and define its images in the community. The use of regression models is the preferred method for measuring discrimination, and the model used in this regard has been developed by Blinder [45] and Oaxaca [46], and is also known as the Blinder-Oaxaca decomposition. It is a valuable tool for the analysis of the wage gap, where the differences in wages are classified into differences between the two groups according to tow added factors: The first is due to the differences in characteristics between the two groups and the other is due to differences in returns (coefficients) between these characteristics.

\section{Causality Relationship between Education Inequality and Income Inequality}

In view of the costs of education and training, poor families, areas and countries cannot afford such costs meaning that the amount of education and training received by their children will be lower than that obtained by rich families, areas and, countries to their children. Since education, as mentioned earlier, is an important determinant of the level of wage or income, this difference will lead to income gaps between poor families, regions and countries on one hand and their rich counterparts on the other hand. Also taking into account the difference in the quality of education available for poor families, areas and countries from that available to rich families, areas and countries, the education gap involves yet another dimension which is the quality of education obtained. The level of education and training has another dimension which cannot be ignored that is the difference in education and training among the mentioned groups will lead to widening the income gap with the passage of time, as the influence comes through affecting the demand and supply of education. On the demand side, the poor parties particularly those in rural areas are characterized by low quantity and quality demand on education as compared to rich Parties particularly in the cities. On the supply side, we find that most governments tend to provide educational services required by the rich and the urban residents, hence the educational benefits reaching the poor and residents of rural areas are less than those reaching the rich and urban areas. Taking into account that the level of education clearly influences the opportunity of getting a job, as well as wages and the level of income, the income of city residents and the rich will increase at a rate greater than the rate of increase of incomes of the poor and residents of rural areas which will increase the income gap between the two groups. Here we will get into a vicious circle where a better quality and quantity education would lead to higher income and a higher income again leads to better education $\cdots$ and so on, so the rich get richer and the poor get more poorer, widening the gap between them with the passage of time on one hand, and forms a vicious circle between education and income distribution on the other hand, as shown in Figure 1.

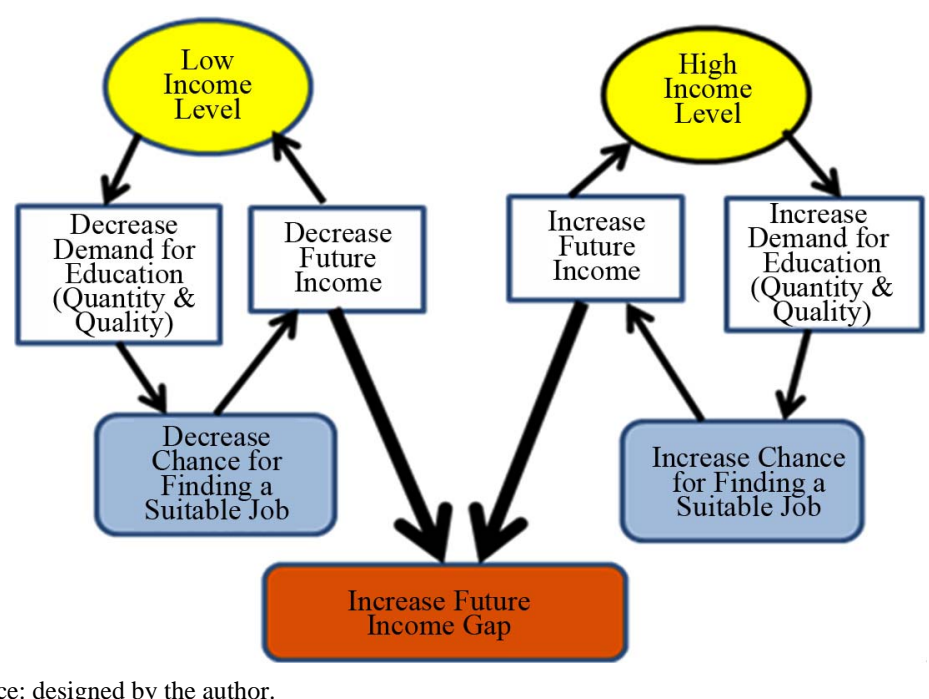

Source: designed by the author.

Figure 1. Causality relationship between income inequality and education inequality. 
As a result to that, education and its distribution within the national economy is an important process that received and still draws the interest of economists, socialists and politicians for its clear impact on the living standards for individuals and for the whole society in both current and future generations.

\section{Education Inequality and Income Inequality in Bahrain}

The distribution of income in the Kingdom of Bahrain between Bahraini families through the analysis of the disparity in wages, income inequality, and disparities in access to education is discussed as follows.

\subsection{Education in Bahrain}

The education indicators in the Kingdom of Bahrain show an increase the rate of literacy between adults from $84 \%$ in the period $1985-1994$ to $88.8 \%$ in the period $1995-2007$, the percentage of overall enrollment in public and higher education in 2007 accounted for $90.4 \%$, this rate exceeds the global average of $67.5 \%$ and places Bahrain in rank one on the Gulf and Arab levels. The percentage of female enrolled in education reached $95.3 \%$ more than for male, which amounted to $85.8 \%$ for the same period. According to a report by the United Nations, the total education guide reached $89.3 \%$, which exceeds the Arab average of $72.6 \%$, the Gulf average at $83.4 \%$, and the global average of $75.3 \%$. The Kingdom of Bahrain came first among Arab countries in the proportion of primary school enrollment rate of over 98\% according to the Global Monitoring Report on Education for all of 2010 issued by the United Nations Educational, Scientific and Cultural Organization [47]. It is worth mentioning that the new statistics released by the Ministry of Education in Bahrain indicate that the proportion of primary school enrollment reaches nearly $100 \%$, since the legal provision for compulsory education in the Education Act of 2005, has enabled the Ministry to follow up and reform all cases of leakage or denial of the study caused by parents, resulting in an annual reduction in the dropout rate of primary education. The proportion of students to teachers in primary schools has risen from a teacher for every 20 students in 1990 to 18 students per teacher in 2000. As for expenditure on education, the percentage has fallen from $12.8 \%$ to $12 \%$ between 1991 and 1999 , and then to $9.4 \%$ in 2007, but the absolute value of the spending on education has increased. Spending on public education as a percentage of GDP had declined from 3\% in 2000 to $2.4 \%$ in 2008 [47]. Bahrain came within the high-performance countries in achieving the goals of education for all in 2010. Bahrain has achieved almost hundred per cent (0.972) in gender equality in education, with a dropout rate of education in Bahrain, less than half percent (0.04\%) in
2007, and the proportion of illiteracy among adults for the same year was 2.46 .

\subsection{Education Level and Work Force}

Figure 2 indicates the need to have a level of education for the chance to work, where the ratio of those enrolled in the labor force increases with high level of education up to secondary school, and then begins to decline due to the high level of remuneration paid to higher levels of education on the one hand and, the low number of holders of such levels from the total labor force in Bahrain.

\subsection{Correlation between Education Status and Wage Level}

There is no doubt in the existence of a close relationship between educational level and the level of remuneration, where the level of remuneration increases as the educational level of workers increase. Figure $\mathbf{3}$ states the link between level of education and average wage in Bahrain in 2006, where the average wage raises with increase in education level.

\subsection{Educational Level and Income Inequality over Time}

Table 1 reflects three dimensions of the relationship between education and income inequality; first it shows the change in the number of households in a certain incomeclass and the level of education over time i.e. dynamic relationship between income distribution and education, for instance, number of illiterate/read only households from 72 in year 1983/1984 to 69 in year 1994/1995 then to 12 in year 2005/2006. The second, it represents the change of number of households in a certain year and education status according to change in income-class i.e. static relationship between income distribution and education, for instance, for intermediate education level, number of households increases from 27 to 94 to 96 from the first three income classes then decreases to reach 5 households in the income class of 24,000 and above.

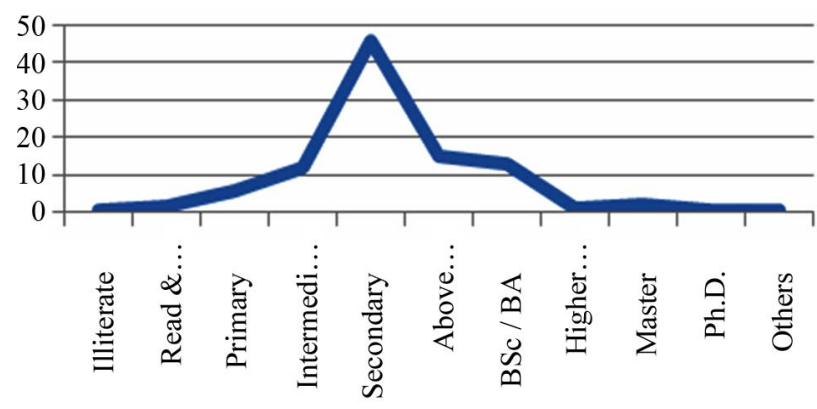

Source: establishment wages structure \& distribution survey, 2006 [48].

Figure 2. Distribution of work force by educational level, 2006. 


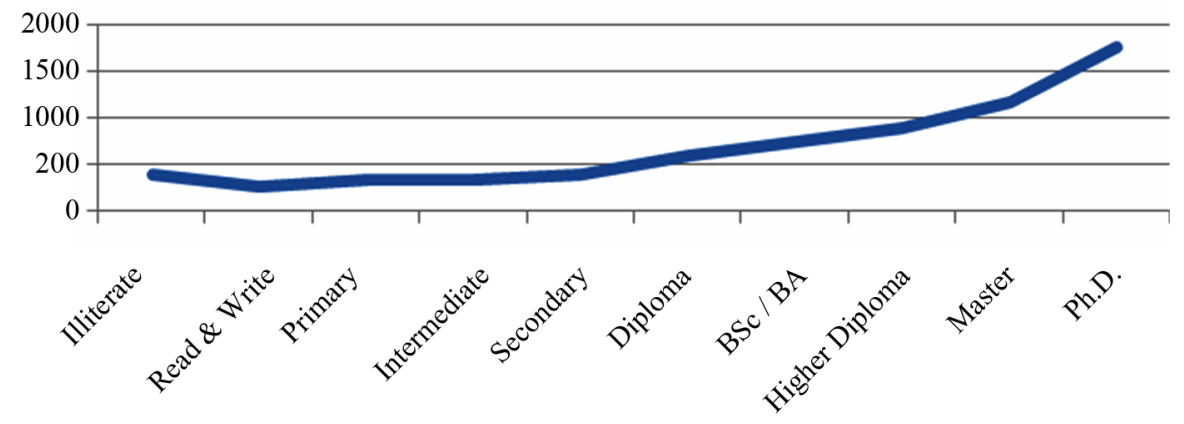

Source: establishment wages structure \& distribution survey, 2006.

Figure 3. Average wage level during month March, 2006 by nationality and education level (Bahraini Dinar).

Table 1. Distribution of HH by annual HH income and educational status (1983/1984-2005/2006).

\begin{tabular}{|c|c|c|c|c|c|c|c|c|c|c|c|c|c|c|c|c|c|c|c|c|c|}
\hline \multirow{3}{*}{$\begin{array}{c}\text { Groups } \\
\text { of annual } \\
\text { HH } \\
\text { income }\end{array}$} & \multicolumn{3}{|c|}{$\begin{array}{l}\text { Illiterate/Read } \\
\text { only }\end{array}$} & \multicolumn{3}{|c|}{ Read \& Write } & \multicolumn{3}{|c|}{ Primary } & \multicolumn{3}{|c|}{ Intermediate } & \multicolumn{3}{|c|}{ Secondary } & \multicolumn{3}{|c|}{ Above Secondary } & \multicolumn{3}{|c|}{$\begin{array}{c}\text { B. Sc./B. A. \& } \\
\text { above }\end{array}$} \\
\hline & 1983/ & 1994/ & 2005/ & / 1983/ & / 1994/ & 2005/ & 1983/ & | 1994/ & / 2005/ & 1983/ & 1994/ & 2005/ & / 1983/ & | 1994/ & / 2005/ & / 1983/ & / 1994/ & / 2005/ & / 1983/ & / 1994/ & / 2005/ \\
\hline & 1984 & 1995 & 2006 & 1984 & 1995 & 2006 & 1984 & 1995 & 2006 & 1984 & 1995 & 2006 & 1984 & 1995 & 2006 & 1984 & 1995 & 2006 & 1984 & 1995 & 2006 \\
\hline $\begin{array}{l}\text { less than } \\
2400\end{array}$ & 72 & 69 & 12 & 8 & 22 & 6 & 7 & 13 & 8 & 2 & 27 & 3 & 1 & 39 & 12 & 0 & 4 & 2 & 1 & 8 & 2 \\
\hline $2400-$ & 122 & 176 & 50 & 49 & 102 & 24 & 31 & 97 & 38 & 20 & 94 & 41 & 16 & 130 & 48 & 3 & 47 & 8 & 1 & 46 & 4 \\
\hline $4800-$ & 83 & 134 & 30 & 43 & 88 & 28 & 24 & 104 & 53 & 26 & 96 & 79 & 31 & 143 & 109 & 12 & 51 & 11 & 3 & 101 & 12 \\
\hline $7200-$ & 60 & 69 & 57 & 28 & 53 & 30 & 12 & 30 & 46 & 23 & 49 & 67 & 18 & 93 & 107 & 7 & 33 & 14 & 3 & 76 & 24 \\
\hline $9600-$ & 25 & 59 & 42 & 28 & 29 & 24 & 15 & 25 & 34 & 4 & 26 & 47 & 17 & 61 & 77 & 3 & 31 & 20 & 3 & 67 & 16 \\
\hline $12,000-$ & 19 & 51 & 36 & 17 & 17 & 30 & 8 & 20 & 46 & 2 & 17 & 36 & 9 & 39 & 83 & 5 & 21 & 22 & 7 & 69 & 34 \\
\hline 15000 & 9 & 12 & 29 & 10 & 20 & 20 & 3 & 10 & 18 & 2 & 10 & 32 & 3 & 23 & 43 & 8 & 23 & 17 & 2 & 41 & 33 \\
\hline 18000 & 6 & 17 & 26 & 10 & 12 & 18 & 4 & 9 & 21 & 5 & 6 & 26 & 5 & 35 & 66 & 2 & 11 & 33 & 6 & 60 & 47 \\
\hline $24,000+$ & 8 & 12 & 26 & 11 & 21 & 15 & 5 & 5 & 24 & 3 & 5 & 22 & 10 & 30 & 55 & 5 & 24 & 31 & 8 & 104 & 118 \\
\hline Total & 404 & 599 & 308 & 204 & 364 & 195 & 109 & 313 & 288 & 87 & 330 & 353 & 110 & 593 & 600 & 45 & 245 & 158 & 34 & 572 & 290 \\
\hline
\end{tabular}

Source: Central Informatics Organization, Household expenditure and income surveys 1983/1984, 1994/1995, and 2005/2006, Bahrain [49].

The third dimension is changes in the number of households in a specific year and certain household income class with the change in the level of education; for instance, for the income-class ranged from 15,000 to 18,000 in year 2005/2006, the number of households decreased from 29 to 20 then to 18 households in education levels illiterate/ read only, read and write, and primary respectively then increased to 32 and 43 households for education status intermediate and secondary respectively.

\section{Causes of Education Inequality in Bahrain}

In spite of a decrease in the education inequality coefficient during 1980-2006 period from 63.1 to 60.8 , to 48.5 , to 44.3 , and to 39.1 in the years $1980,1983,1994 / 1995$, 2000, and finally 2005/2006 respectively as shown Figure 4, but the education inequality value is still high.
GINI Education

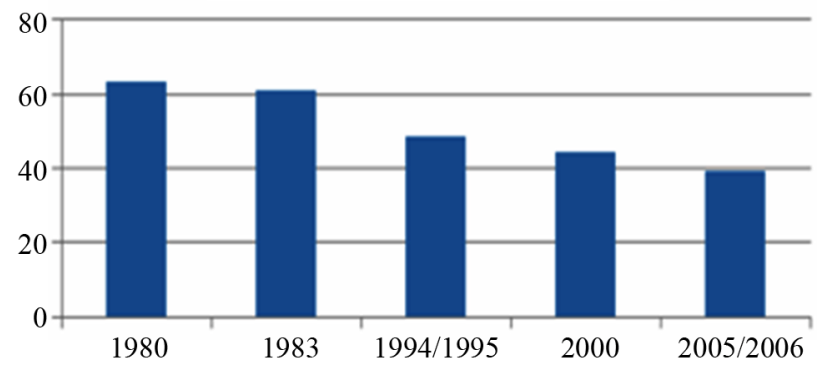

Source: Thomas, Wang, and Fan (2001) for years 1980 and 2000, the author for other years.

Figure 4. Gini education in Bahrain (1980-2005/2006).

As shown before, the demand for education affects the level of per capita income and can be then a reason of income inequality. The difference in the demand for 
education in both quality and quantity may be due to the disparity in tuition fees on the one hand and disparities in the availability of schools with high Geographical efficiency on the other. The author argues that the main factors affect education inequality in Bahrain is the difference in effectiveness between different educational institutions in the Kingdom and the income inequality among governorates. There are a lot of educational institutions that offer special curriculums like the America, English, Indian and Pakistani schools, as well as higher education institutions, which leads to varying efficiency of graduates and therefore their ability to engage in the labor market. Also, we should not overlook the great disparity in the study costs between those institutions and the impact on income distribution at the present time and in the future. In the following section, causes of education inequality in Bahrain will be analyzed.

\subsection{Difference in Income Level among Governorates}

As discussed above, the income level is an important factor of demand and supply of education. The government provides high quality/quantity education in rich areas/ rich families. At the same time, high-income level areas/ families are able to demand high quality and quantity education. The two effects, demand for and supply of education, support education inequality. Table 2 reflects the distribution of income between the governorates of the Kingdom. The table shows that $18 \%$ of the families of the Northern governorate have an average annual income between 7200 and 9600 dinars. It reports that 11\%, 9\%, $9 \%, 6 \%$ and $5 \%$ of the families of the Muharraq, Central, Southern, Northern and the Capital governorates get the highest level of the average annual income.

\subsection{Difference in Costs of Study}

The difference in the cost of education is one of the characteristics of education in Bahrain, in view of the remark able diversity in the quality of educational institutions, where the majority use a curriculum designed by them, mostly a mixture between the curriculums of the Ministry of Education in Bahrain and other curriculums presented by them to characterize the school from others. Table 3 shows the disparity in tuition and registration in some private schools operating in Bahrain. Private schools in Bahrain are divided into foreign private schools, and national private schools. The cost of study and registration in the first type is more than the second. The study in the first type is in one foreign language and not in Arabic, while educational language in national private schools is a mixture of a foreign language-usually English-and Arabic language. Children of rich families usually study in the first type, while children of middle families attend the second type, as for poor and low-income families; they send their children to government schools, where study and registration is free.

\subsection{Difference in the Availability of Private Schools among Governorates}

This disparity may be in terms of quantity, quality or both quantity and quality. Figure 5 states that the regions that suffer from the low level of family income are those regions that suffer from a lack of the number of private schools. The number of families in the southern province whose average annual income comes between 12,000 and 18,000 is 10 families from a total of 95 families or $10.5 \%$ in 2005/2006, Muharraq Governorate ranked second in terms of lower number of households. The number of private schools in these two Governorates is two schools in the southern Governorate and seven schools in the Muharraq Governorate. In contrast, the number of private schools in Central and Capital Governorates is 25 and 21 schools respectively in the same year, the number of families in both Provinces whose average annual income is between 12,000 and 18,000 is 99 and 104 respectively, representing $14.4 \%$ and $13.4 \%$ from the total sample.

Table 2. Average of Bahrain households annual income by governorate (2005/2006).

\begin{tabular}{|c|c|c|c|c|c|c|}
\hline \multirow{2}{*}{ Annual income classes } & \multicolumn{5}{|c|}{ Governorate } & \multirow{2}{*}{ Total } \\
\hline & Capital & Muharraq & Northern & Middle & Southern & \\
\hline Less than 2400 & 11 & 7 & 14 & 11 & 2 & 45 \\
\hline $2400-$ & 38 & 29 & 72 & 64 & 10 & 213 \\
\hline 4800 & 45 & 49 & 126 & 78 & 24 & 322 \\
\hline $7200-$ & 40 & 56 & 141 & 99 & 9 & 345 \\
\hline $9600-$ & 26 & 45 & 104 & 73 & 12 & 260 \\
\hline $12,000-$ & 35 & 39 & 104 & 99 & 10 & 287 \\
\hline $15,000-$ & 24 & 31 & 73 & 54 & 10 & 192 \\
\hline $18,000-$ & 19 & 49 & 68 & 94 & 7 & 237 \\
\hline $24,000-$ & 13 & 26 & 39 & 43 & 2 & 123 \\
\hline $30,000+$ & 15 & 34 & 36 & 74 & 9 & 168 \\
\hline Total & 266 & 365 & 777 & 689 & 95 & 2192 \\
\hline$\%$ of total & 12.14 & 16.65 & 35.45 & 31.43 & 4.33 & 100.00 \\
\hline
\end{tabular}

Source: Central Informatics Organization, household expenditure and income survey 2005/06, Bahrain. 
Table 3. Tuition and registration fees at selected private schools in Bahrain 2009/2010.

\begin{tabular}{|c|c|c|c|c|c|}
\hline No. & School name & Curriculum & Annual tuition fees & Education language & Registration fees \\
\hline \multicolumn{6}{|c|}{ First: Foreign Private Schools } \\
\hline 1 & Al Mahd & British & $\begin{array}{l}\text { K.G. (BD 450) } \\
\text { Grades } 1 \text { - } 6 \text { (BD 650) } \\
\text { Grades } 7 \text { - } 9 \text { (BD 850) } \\
\text { Grades } 10 \text { - } 11 \text { (BD 1050) }\end{array}$ & English & 25 \\
\hline 2 & Saint Christopher & British & $\begin{array}{l}\text { K.G. (BD 2333) } \\
\text { Pre- school (BD 2886) } \\
\text { Grades } 1 \text { - } 2 \text { (BD 2886) } \\
\text { Grades } 3 \text { - } 6 \text { (BD 3276) } \\
\text { Grades } 7 \text { - } 8 \text { (BD 4104) } \\
\text { Grades } 9 \text { - } 11 \text { (BD 5148) } \\
\text { Grades } 12 \text { - } 13 \text { (BD 6261) }\end{array}$ & English & 50 \\
\hline 3 & Delmon & British & $\begin{array}{l}\text { K.G. (BD 870) } \\
\text { Perception (BD 870) } \\
\text { Grades } 1 \text { - } 2 \text { (BD 900) } \\
\text { Grades } 3 \text { - } 6 \text { (BD 1050) }\end{array}$ & English & 100 \\
\hline 4 & French & French & $\begin{array}{l}\text { K.G. French and Bahraini students (BD 1402) others (BD 1694) } \\
\text { Grades } 1 \text { - } 5 \text { French \& Bahraini (BD 1733) others (BD 2058) } \\
\text { Grades } 6 \text { - } 12 \text { French \& Bahraini (BD 2659) others (BD 3215) }\end{array}$ & French & 250 \\
\hline 5 & British & British & $\begin{array}{l}\text { K.G. (BD 2055) } \\
\text { Pre-school (BD 2613) } \\
\text { Grades } 1 \text { - } 2 \text { (BD 2613) } \\
\text { Grades } 3 \text { - } 5 \text { (BD 2973) } \\
\text { Grades } 6 \text { - } 8 \text { (BD 3720) } \\
\text { Grades } 9 \text { (BD 3891) } \\
\text { Grades } 10 \text { - } 11 \text { (BD 4071) } \\
\text { Grades } 12 \text { - } 13 \text { (BD 5316) }\end{array}$ & English & 100 \\
\hline 6 & $\begin{array}{c}\text { International } \\
\text { Bahrain }\end{array}$ & American & $\begin{array}{l}\text { K.G. (BD 5366) } \\
\text { Grades } 1 \text { - } 6 \text { (BD 5366) } \\
\text { Grades } 7 \text { - } 8 \text { (BD 5646) } \\
\text { Grades } 9 \text { - } 12 \text { (BD 5931) }\end{array}$ & English & 455 \\
\hline 7 & International IMI & American & $\begin{array}{l}\text { K.G. (BD 1056) } \\
\text { Grades } 1 \text { - } 6 \text { (BD 1089) } \\
\text { Grade } 7 \text { (BD 1452) } \\
\text { Grade } 8 \text { (BD 1551) } \\
\text { Grade } 9 \text { (BD 1683) } \\
\text { Grades } 10 \text { - } 12 \text { (BD 2362.5) }\end{array}$ & English & 150 \\
\hline \multicolumn{6}{|c|}{ Secondly: National Private Schools } \\
\hline 1 & Ibn Khaldoun & American + IB & $\begin{array}{l}\text { K.G. (BD 2025) } \\
\text { Grades } 1 \text { - } 5 \text { (BD 2450) } \\
\text { Grades } 6 \text { - } 8 \text { (BD 2800) } \\
\text { Grades } 9 \text { - } 10 \text { (BD 3175) } \\
\text { Grades } 11 \text { - } 12 \text { (BD 3550) }\end{array}$ & English \& Arabic & 100 \\
\hline 2 & Bayan & American + IB & $\begin{array}{l}\text { K.G. } 1 \text { (BD 1980) } \\
\text { K.G. } 2 \text { (BD 2340) } \\
\text { Grades } 1 \text { - } 5 \text { (BD 2540) } \\
\text { Grades } 6 \text { - } 9 \text { (BD 2840) } \\
\text { Grades } 10 \text { - } 12 \text { (BD 3180) }\end{array}$ & English \& Arabic & 200 \\
\hline 3 & Naseem & American + IB & $\begin{array}{l}\text { K.G. } 1 \text { (BD 1820) } \\
\text { K.G. } 2 \text { (BD 1920) } \\
\text { Grades } 1 \text { - } 5 \text { (BD 2150) } \\
\text { Grades } 6 \text { (BD 2400) } \\
\text { Grades } 7 \text { - } 8 \text { (BD 2410) } \\
\text { Grades } 9 \text { - } 10 \text { (BD 2630) } \\
\text { Grades } 11 \text { - } 12 \text { (BD 2680) }\end{array}$ & English \& Arabic & 200 \\
\hline
\end{tabular}

Compiled by the author from private education department, ministry of education, Bahrain. 


\subsection{Difference in Spending on Education}

The level of education affects the awareness of importance of education and its ability to improve the family income-class. Table 4 represents that the spending on education divers from one level of education to another on one hand and from one governorate to another on the other hand. Capital governorate is spending more on Preprimary and primary education and tertiary-university and higher education. However, Central and Muharraq governorates are spending more on secondary education.

\section{Conclusion}

No doubt that education and education inequality are important and influential factors on income distribution, through their impact on the level of remuneration and the career opportunities available. Based on the analysis of data from household expenditures and income surveys shows a positive correlation between the level of education of the family head and family income. Poor families and poor areas suffer from low chances to obtain high quality education, and then less chance of getting a job with an appropriate salary which leads to low income and a lesser chance for a quality education leading to a vi-

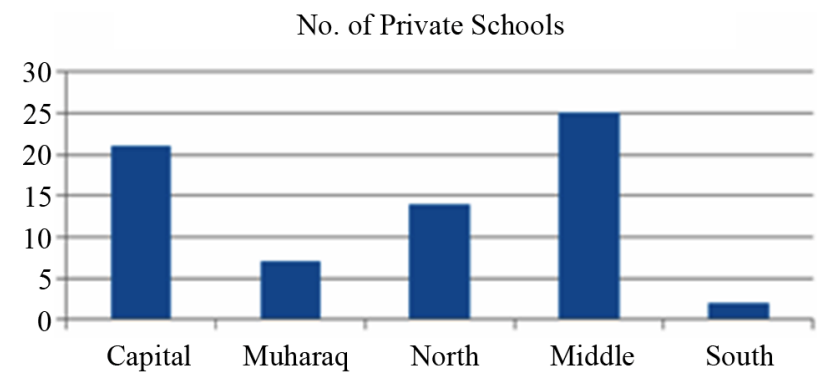

Source: household expenditure and income survey 2005/06.

Figure 5. Distribution of private schools by governorate 2009/2010.

Table 4. Average annual per capita expenditure on education by governorate and the education level of the head of HH.

\begin{tabular}{cccccc}
\hline \multirow{2}{*}{$\begin{array}{c}\text { Education status of } \\
\text { the head of HH }\end{array}$} & \multicolumn{5}{c}{ Governorates } \\
\cline { 2 - 6 } & Capital & Muharraq Northern & Central & Southern \\
\hline $\begin{array}{c}\text { Pre-primary and } \\
\text { primary education }\end{array}$ & 47.4 & 17.3 & 22.6 & 25.9 & 21.6 \\
$\begin{array}{c}\text { Secondary education } \\
\begin{array}{c}\text { Post-secondary/ } \\
\text { non-tertiary } \\
\text { education }\end{array}\end{array}$ & 6.7 & 7.7 & 2.8 & 7.8 & 4.8 \\
$\begin{array}{c}\text { Tertiary-university } \\
\text { and higher education }\end{array}$ & 52.9 & 23.6 & 21.9 & 39.3 & 15.1 \\
$\begin{array}{c}\text { Education not } \\
\text { definable by level }\end{array}$ & 3.9 & 6.4 & 2.9 & 19.4 & 8.9 \\
\hline
\end{tabular}

cious cycle in the relationship between level of income and education, which consequently leads to widening the income gap between future generations. The difference in the educational institutions available in Bahrain causes disparity in the skills of graduates, leading to a difference in the career opportunities available, and then wages levels. Inequality in education attainment in Bahrain had been declining during the period 1980-2006, this results support the theoretical and empirical literature on education and income inequality nexus. For instance, Thomas, Wang and Fan [50] measured Gini education for population age over fifteen, using two different methods for 85 countries from 1960 to 1990 . They found that education inequality for most countries in their sample declined during the period. The important sources of education inequality in Bahrain are disparities in education costs, availability of private schools in different governorates, and in spending on education. One issue for improving income inequality in Bahrain is to improve education inequality. So, the policy-makers in Bahrain should pay more attention to distribution of private schools among governorates and education cost among these schools.

\section{REFERENCES}

[1] H. H. Abdelbaki, "The Impact of Macroeconomic Policies on Income Distribution: An Empirical Study of Egypt,” PhD Thesis, Development and Project Planning Centre, Bradford University, Bradford, 2001.

[2] V. Tanzi, "Fundamental Determinants of Inequality and the Role of Government," IMF Working Paper, WP/98/ 178, International Monetary Fund, Washington DC, 1998.

[3] B. Clements, "Income Distribution and Social Expenditure in Brazil,” IMF Working Paper, WP/97/120, International Monetary Fund, Washington DC, 1997.

[4] G. S. Becker and B. R. Chiswick, "Education and the Distribution of Earnings," American Economic Review, Vol. 56, No. 1-2, 1966, pp. 358-369.

[5] M. Adelman and C. Morris, "Economic Growth and Social Equity in Developing Countries,” Stanford University Press, Stanford, 1973.

[6] H. B. Chenery and M. Syrquin, "Patterns of Development: 1950-1970,” Oxford University Press for the World Bank, London, 1975.

[7] A. Marin and G. Psacharopoulos, "Schooling and Income Distribution," Review of Economics and Statistics, Vol. 58, No. 3, 1976, pp. 332-338. doi:10.2307/1924955

[8] B. R. Chiswick, "Earnings Inequality and Economic Development,” Quarterly Journal of Economics, Vol. 85, No. 1, 1971, pp. 21-39. doi:10.2307/1881838

[9] C. R. Winegarden, "Schooling and Income Distribution: Evidence from International Data,” Economica, Vol. 46, No. 181, 1979, pp. 83-87.

[10] R. Ram, "Population Increase, Economic Growth, Educational Inequality \& Income Distribution: Some Recent Evidence,” Journal of Development Economics, Vol. 14, 
No. 3, 1984, pp. 419-428. doi:10.1016/0304-3878(84)90069-5

[11] R. Ram, "Can Educational Expenditures Reduce Income Inequality in Less-Developed Countries?” Economics of Education Review, Vol. 8, No. 2, 1989, pp. 185-189. doi:10.1016/0272-7757(89)90006-X

[12] K. Sylwester, "Can Education Expenditures Reduce Income Inequality?” Economics of Education Review, Vol. 21, No. 1, 2002, pp. 43-52.

[13] G. Glomn and B. Ravikumar, "Public versus Private Investment in Human Capital: Endogenous Growth and Income Inequality,” Journal of Political Economy, Vol. 100, No. 4, 1992, pp. 818-834.

[14] G. Saint-Paul and T. Verdier, "Education, Democracy, and Growth, Centre for Economic Policy Research,” Discussion Paper No. 613, London, 1992.

[15] Z. Eckstein and I. Zilcha, "The Effect of Compulsory Schooling on Growth, Income Distribution and Welfare," Journal of Public Economics, Vol. 54, No. 3, 1994, pp. 339-359. doi:10.1016/0047-2727(94)90040-X

[16] I. Zhang, "Optimal Investments in Education and Endogenous Growth,” Scandinavian Journal of Economics, Vol. 98, No. 3, 1996, pp. 387-404.

[17] E. Jimenez, "The Public Subsidization of Education and Health in Developing Countries: A Review of Equity and Efficiency,” Research Observer, Vol. 1, No. 1, 1986, pp. 111-129. doi:10.1093/wbro/1.1.111

[18] H. G. Lewis, "Unionism and Relative Wages in the United States,” University of Chicago Press, Chicago, 1963.

[19] R. D. Plotnick, “Trends in Male Earnings Inequality," Southern Economic Journal, Vol. 48, No. 3, 1982, pp. 724732. doi:10.2307/1058663

[20] R. Freeman and J. L. Medoff, “What Do Unions Do?” Basic Books, New York, 1984.

[21] M. Curme and L. M. Khan, "Unions and Nonunion Wage Dispersion," Review of Economics and Statistics, Vol. 69, No. 4, 1987, pp. 600-607. doi:10.2307/1935954

[22] M. Gittleman and B. Pierce, "New Estimates of Union Wage Effects in the US," Economics Letters, Vol. 95, No. 2, 2007, pp. 198-202. doi:10.1016/j.econlet.2006.10.003

[23] F. Modigliani and R. Brumberg, "Utility Analysis and the Consumption Function: An Interpretation of Cross-Section Data,” In: K. Kurihara, Ed., Post-Keynesian Economics, Rutgers University Press, New Brunswick, 1954.

[24] A. Ando and F. Modigliani, "The Lifecycle Hypothesis of Saving: Aggregate Implications and Tests," American Economic Review, Vol. 53, No. 1, 1963, pp. 55-84.

[25] E. Wolff, "Poverty and Income Distribution," WileyBlackwell, Hoboken, 2009.

[26] G. Orfield, "The Growth of Segregation in American School," National School Boards Association, Alexandria, 1993.

[27] G. Orfield and C. Lee, "Racial Transformation and the Changing Nature of Segregation,” The Civil Rights Project of Harvard University, Cambridge, 2006.

[28] G. S. Becker, “The Economics of Discrimination,” 2nd
Edition, University of Chicago Press, Chicago, 1971.

[29] E. S. Phelps, "The Statistical Theory of Racing and Sexism,” American Economic Review, Vol. 62, 1972, pp. 659-661.

[30] K. J. Arrow, "Models of Job Discrimination,” In: A. H. Pascal, Ed., Racial Discrimination in Economic Life, D.C. Heath, Lexington, 1972, pp. 83-102.

[31] K. J. Arrow, "Some Mathematical Models of Race in The Labor Market,” In: A. H. Pascal, Ed., Racial Discrimination in Economic Life, D.C. Heath, Lexington, 1972, pp. 83-102.

[32] K. J. Arrow, “The Theory of Discrimination,” In: O. Ashenfelter and A. Rees, Eds., Discrimination in Labor Markets, Princeton University Press, Princeton, 1973.

[33] D. Aigner and G. G. Cain, "Statistical Theories of Discrimination in Labor Markets," Industrial Labor Relations Review, Vol. 30, 1977, pp. 175-187.

[34] M. Reich, “The Economics of Racism,” In: D. M. Gordon, Ed., Problems in Political Economy, 2nd Edition, D.C. Heath, Lexington, 1977.

[35] M. Reich, "Who Benefit from Racism? The Distribution among Whites of Gains and Losses from Racial Inequality,” Journal of Human Resources, Vol. 13, 1978.

[36] M. Reich, "Changes in the Distribution of Benefits from Racing in The 1960s,” Journal of Human Resources, Vol. 16, No. 2, 1981, pp. 314-321. doi:10.2307/145516

[37] M. Reich, “Racial Inequality,” Princeton University Press, Princeton, 1981.

[38] M. Reich, "Postwar Income Differences: Trends and Theories,” In: G. Mangrum and P. Philips, Eds., Three Worlds of Labor Economics, M.E. Sharpe, White Plains, 1988.

[39] G. C. Loury, "Discrimination in the Post-Civil Rights Era: Beyond Market Interactions," Journal of Economics Perspectives, Vol. 12, No. 2, 1998, pp. 117-126. doi:10.1257/jep.12.2.117

[40] G. C. Loury, “The Anatomy of Racial Inequality,” Harvard University Press, Cambridge, 2002.

[41] B. P. Bergmann, "Occupational Segregation, Wages and Profits When Employers Discriminate by Race or Sex," Eastern Economic Journal, April-July 1974, pp. 103-110.

[42] M. H. Stevenson, "Relative Wages and Sex Segregation by Occupation,” In: C. B. Lloyd, Ed., Sex, Discrimination, and the Division of Labor, Columbia University Press, New York, 1975.

[43] F. D. Blau and W. E. Hendricks, "Occupational Segregation by Sex: Trends and Prospects," Journal of Human Resources, Vol. 14, No. 2, 1979, pp. 1979-210. doi:10.2307/145642

[44] F. D. Blau, "Discrimination against Women: Theory and Evidence,” In: W. Darity Jr., Ed., Labor Economics: Modern View, Kluwer-Hijhoff, Boston, 1984, pp. 53-89. doi:10.1007/978-94-009-5636-0 3

[45] A. Blinder, "Wage Discrimination: Reduced Form and Structural Estimates,” Journal of Human Resources, Vol. 7, No. 4, 1973, pp. 436-455. doi:10.2307/144855

[46] R. Oaxaca, "Male-Female Wage Differentials in Urban 
Labor Market,” International Economic Review, Vol. 14, No. 3, 1973, pp. 693-709. doi:10.2307/2525981

[47] UNISCO, “General Regional Overview: Arab Countries -Path to Equality,” The Global Report about Education for All, 2010.

[48] Report for Establishment Survey of Wages Structure \& Distribution Survey, Central Informatics Organisation, General Directorate of Statistics, Bahrain, 2006.
[49] Household Expenditure and Income Surveys 1983/84, 1995/96 and 2005/06, Central Informatics Organisation, General Directorate of Statistics, Bahrain.

[50] V. Thomas, Y. Wang and X. Fan, "Measuring Education Inequality: Gini Coefficient of Education, World Bank Research Paper No. 2525,” The World Bank, Washington DC, 2001. 